\title{
THE HEALTH BEHAVIOUR OF BLACK INSULIN DEPENDENT DIABETIC PATIENTS
}

\section{Gladness Lindiwe Xaba and Sandra Ruth Dewar}

\section{INTRODUCTION}

A person with a chronic illness has to alter his life in some way. Ruzick (1984) suggests that whether or not he complies with a medical $r$ he is determined by his perception of the situation.

Accurate measurement of patient compliance with medical regimes is notably difficult. Most authorities agree that knowledge alone is insufficient in bringing about compliance and that the key to success with long term treatment regimes is responsible for self care and an adequate support system which encompasses both professional and non-professional support (Finnerty 1978. Becker \& Maiman 1980. Dunn 1986). Cox's interaction model of Client Heal th Behaviour attempts to explain human responses to ill heal th and medical treatment; central to this model is the relationship between client and health care provider. Additional factors to be considered within this model include client educational standard, environmental resources, motivational level, disease understanding and affective response (Cox 1982).

s model forms the theoretical framework of this work which aims to explore some aspects of how Black Zulu-speaking diabetic patients cope with their disease. The prevalence of diabetes mellitus has been shown to be increasing in all South African populations (Seedat 1985).

The importance of the condition is reflected in the number of patients admitted to the two study hospitals for diabetic treatment; in seven consecutive months during 1986, a total of 1719 diabetic patients were seen.

The study investigates social circumstances and perceptions of their complaint of 20 insulin dependent adult diabetic patients utilizing the outpatient departments of 2 busy general hospitals and administered by the KwaZulu Department of Health. Both these hospitals train students for the Integrated Diploma in Nursing. Diabetic clients attend a specific diabetic clinic in Hospital A whereas in Hospital $B$, they attend the general medical outpatient clinic. At both hospitals insulin prescriptions are issued monthly and patients are given 12

\begin{abstract}
This descriptive retrospective study explores the perceptions and experiences relating to their discease of 20 adult Black insulin - dependent diabetic clients in terms of Cox's Interaction Model of Client

iii) establish the perspective of registered nursing staff regarding diabetes and their expectations of insulin-dependent diabetic clients

iv) determine monthly clinic attendance records as an indicator of treatment compliance and service utilisation.
\end{abstract} Health Behaviour. Cognitive and affective responses were investigated by means of structured interviews. Questionnaires completed by 30 registered nurses examined by their impressions of diabetic patients" motivation and levels of satisfaction with their care. Findings are discussed and recommendations made.

\section{Uittreksel}

Hierdie beskrywerde studie ondersoek respektiewelik die persepsies en ondervindinge van 20 volwasse Swart insulien -afhanklike diabetiese kliènte, in terme van die Cox Interaksionele Model van Gesondheidsgedrag.

Kognitiewe sowel as affektiewe response is ondersoek d.m.v. gestruktureerde onderhoude met, en vraelyste voltooi deur 30 geregistreerde verpleegkundiges wat hul indrukke van diaberiese pasiënte se motiverings - en tevredenheidsvlakke met die sorg wat hulle ontwang, ondersoek. Bevindinge word bespreeft en aanbevelings gemaak.

insulin syringes each thus requiring a monthly visit to the clinic by the client. Equipment for home glucose monitoring is not supplied and blood sugar levels are done once a month at the respective clinios.

\section{OBJECTIVES OF STUDY}

These were to:-

i) identify the responses of Black adult insulin-dependent diabetics toward their disease

ii) enquire into the experience of the family living with a diabetic member

\section{Procedure and sample}

During the period 1 January 1987 to 30 June 1987,20 insulin-dependent diabetics were selected, all of whom agreed to participare in the project. Criteria for selection required clients to have had a medically-confirmed diagnoses of insulin-dependent diabetes millitus (I.D.D.M.) for at least one year and to have been resident in and around the two study hospitals and attending clinics at the respective hospitals. Hospital patient records were used to gain access to I.D.D.M. patients and every tenth card was drawn until a quota of 10 subjects fulfilling selection criteria from each hospital was achieved.

In order to probe the attitudes of registered nursing staff, a convenience sample of 15 nurses attending staff meetings at each hospital was selected.

A retrospective descriptive study design was employed, making use of standardised interviews implemented by the researcher with the I.D.D.M. clients. A standardised questionnaire was distributed to the registered nursing staff for their independent completion. Clients were seen at least twice, on the first occasion at the clinic and on the second, either in their own homes or at the clinic, at which meeting a family member was invited to participate.

Review of the clinic records over a 10-month period revealed the patients' attendance records, random blood sugar levels, and details of general health.

\section{RESULTS}

Data were analysed according to the central components of Cox's model, namely:background demographic variables, client singularity (defined as a compound of 
background variables, motivation, cognitive appraisal and affective response), client professional interaction and health outcome.

\section{Demographic information $(\mathbf{n}=20)$}

The mean age of the clients was 46 years (range $14-73$ years). Of the group $12(60 \%)$ were female and $8(40 \%)$ were male. Twelve clients had $8-12$ years schooling. Two of these had tertiary education, whereas eight clients had received 4.7 years schooling. Of the 6 unemployed people 2 were scholars and 3 were receiving state pensions

The mean monthly income of employed members of the group was R523 (std. deviation R402.27). All clients were resident with family members.

\section{MOTIVATION}

In attempting to determine this variable, questions relating to the following were asked of the clients:-

i) nature of information given about diabetes by heal th professionals, and the use made of this information

ii) client's desire for competency in managing his condition

iii) depth of understanding of diabetes shown by client.

Eight clients appeared positively motivated, nine gave mixed responses and three responded negatively. All the respondents said that they were given information about diabetes and its management and all thought that they were competent with the giving of insulin injections. Fourteen clients found it difficult to adhere to the diet and nine of them were not taking the recommended berween-meal snacks because they could not afford them or were not hungry.

\section{COGNTTION}

Cognitive appraisal is defined as the patient's interpretation and understanding of his disease and its management. Fifteen patients (75\%) showed a reasonable understanding of the disease, its problems and importance of compliance with the diet, exercise and the insulin regime. Difficulty with meal preparation related to the impression that the diabetic diet is expensive and too different from family food preferences (Table 1). Most respondents $(70 \%)$ knew the importance of eating a snack before strenuous exercise, and all got exercise from their work, sport, housework or gardening.

Five clients were aware of blood and urine monitoring systems and reported the importance of this to coping with their disease, and three $(15 \%)$ were aware of the significance of daily testing of blood sugar and expressed concern about not being able to have testing agents available. None of the clients wore a medic-alen bracelet although a few of them knew about it.
TABLE 1.

Probleme experinenced by familles of IDDM patlents $(n=20)$

Number and Porcent (\%)

\begin{tabular}{|c|c|}
\hline PROBLEMS EXPERIENCED & NUMBER $(x)$ \\
\hline Unpredictabie nature of disecese & $14(70)$ \\
\hline Limited control in soite of complience & $15(75)$ \\
\hline Emotionally draining & $18(80)$ \\
\hline Difficut to acthere to dabedic dier & $12(80)$ \\
\hline Patent orinks too much acohal & $5(25)$ \\
\hline Ditmeurty in preparing meale & $3(15)$ \\
\hline Difmeuty in perticloating in femily life & $4(20)$ \\
\hline
\end{tabular}

\section{AFFECTIVE RESPONSE}

Health behaviour cannot be explained only on the basis of rational thought and understanding as emotions can interfere with cognition and substantially affect behaviour. The affective response was tested by exploring whether the patient experienced negative feelings towards the disease. In $75 \%$ of cases sadness and a sense of loss of good health was expressed. As many as $60 \%$ reported feeling worried about their health, a few (15\%) said they were jealous of non-diabetics and 15\% reported feelings of depression. These emotions seemed to affect dietary compliance but clients reported never missing their insulin doses. Poorly controlled blood sugar levels were experienced as discouraging and demotivating.

On interview, all the families appeared supportive of the diabetic sufferer but fear of the disease and an inability to cure or control it were experienced as highly stressful. Some of the recommendations made by families are listed in Table 2.

TABLE 2.

Recommendatlons made by tamilies to enhance their adjustmont to living with a diabetic person

\begin{tabular}{|c|c|}
\hline RECOMMENDATIONS & NUMBER (x) \\
\hline Greecer fumily invovernent in cere & $18(05)$ \\
\hline Finended ematenea requined & $4(20)$ \\
\hline Communty vieite by nurses & $2(10)$ \\
\hline Tablce inateed of infection & $3(15)$ \\
\hline Alcond renweilitudion progr amme & $4(20)$ \\
\hline 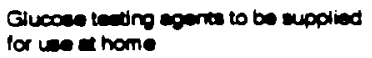 & $5(25)$ \\
\hline
\end{tabular}

Thirteen families (65\%) expressed a desire to be more involved when heal th information is given and were critical of the lack of support they were given by the health services.

\section{CLIENT-PROFESSIONAL INTERACTION}

Cox suggests that this interaction is determined by four components and that its sucess varies according to patient singularity and the health care need that is expressed.

\section{(i) The provision of health information}

Most clients(60\%) gave positive responses with respect to their relationships with the staff. At both clinics the nurses gave diabetes education in regard to its clinical manifestations and management before the doctors arrived for the clinics. Late arrival meant missing the talks. Several admitted forgetting what was said. No written material was handed out. Clients knowledge of foot care, the importance of wearing shoes and routine eye testing was poor.

Although 11 patients reported eye problems, none had been referred for eye testing. As part of the questionnaire completed by the registered nurses, respondents were asked to rank a list of items related to diabetic care, and $90 \%$ ranked eye testing as the least important aspect of care.

All clients were competent in insulin administration and $17(85 \%)$ were rotating th injection sites.

The nurses in general appeared to have favourable impressions as regards treatment compliance, and $27(90 \%)$ were of the impression that patients are well motivated in the control of their disease.

The most important reasons they gave for non-compliance were:

1) dietary problems (40\%) and one nurse commented thus:- "The moment the nurses mention vegetables and fruit. patients stop listening because they cannot afford these".

2) inadequate knowledge of the disease (33\%)

3) financial difficulty (65\%)

In general, nursing staff seemed over-estimate patient satisfaction with their care and their motivation as far as disease control is concerned.

\section{(ii) Degree of emotional support given by} the staff

The relationship between client and staff was difficult to assess accurately. Clients reported liking the staff and were obviously reticent about negative criticism. Many were unhappy about seeing different doctors at each visit, and would prefer continuity in this area. The greater proportion of time at the clinics appeared to be spent with the nurses rather than the doctors. Most nurses (90\%) felt that the medical and nursing support of patients was adequate and were more critical of lack of support from the families.

\section{(iii) Decisional Control}

Decisional control refers to the degree of individual decision making regarding health. This aspect was difficult to evaluate and the impression of the authors is that clients are largely passive within the health care system. 
When asked to make suggestions for improving the diabeticheal th service several were reluctant to comment, others did not have anything to say, and all said that they doubted if any of their suggestions would be considered or implemented.

\section{(iv) Utilization of the service}

This was measured by clinic attendance over a 10 month period, as recorded on the patients' clinic cards.

Those who were $100 \%$ compliant with clinic attendance over 10 months numbered $6(30 \%)$ The reasons given for irregular clinic attendance included:

(i) an adequate supply of insulin

(ii) waiting periods of 4 - 9 hours at the clinic

From this it was apparent that the reasons for regular clinic attendance and monthly blood glucose monitoring was ill-understood.

S.moflaction with care appeared directly linked to the amount of time spent at the clinic. Better clinic attendance was observed at Hospital A where there is a separate diabetic clinic. In addition snacks are available for waiting clients at this hospital and lengthy waiting times have been reduced by storing the patient records in the clinic itself. Only $9(45 \%)$ clients reported satisfaction with their medical care. Major reasons for dissatisfaction centered around long waiting times at clinics, inability to choose their doctor and being given too little equipment.

\section{HEALTH OUTCOME}

Five clients appeared to be free from complications of diabetes, $8(40 \%)$ were hypertensive, $11(55 \%)$ reported eye and 2 reported peripherol vascular problems. All clients had fluctuating blood glucose levels - 6 sh-ed readings below $9,5 \mathrm{mmol} /$ and the re ander were all above this level. Only 2 of the respondents considered themselves to be generally well and free of other illnesses.

\section{DISCUSSION}

Health outcome in long term illness is influenced by the type of service and level of Satisfaction with the treatment regime. Lack of personalized care discourages regular clinic utilization (Finnerty 1978). The client their families and the nurses have all expressed the belief that the service is not adequate and the registered nurses have identified one of the problems as inadequate patient education. This is a result of a lack of in-service education for the nurses and overcrowding in the wards which does not afford nurses the time to give the necessary health education to new diabetic patients and their relatives.

Both the patients and families expressed the desire for more information and inclusion of families in the management of diabetes. The need for follow up by community nurses was often expressed.

Dietary compliance appeared to be a major problem. Both Glasgow and McCaul (1986) and McCullock (1983) warn that the main reason why diet fails is not that the diet is wrong but that methods of teaching it and maintaining interest are ineffective. It would appear that few studies have evaluated vigorously the effectiveness of educational strategies to improve dietary compliance and this is one area in which parient responsibility and decisional control can be improved.

Diabetes is a chronic condition which requires both a staff intensive approach and multidisciplinary involvement if it is to be successful. Given the prevalence of diabetes in the black community and the restrictions imposed on lifestyle by the onset of complications, this disease deserves much greater emphasis by the health service in the area under study. Nurses are not fully in touch with patient perceptions of their disease and how they cope. Long term support of diabetics is needed to maintain motivation and compliance. The major recommendations of this study are that:

1. clinic administration be improved to reduce waiting time, provide after hours service and more personalised attention;

2. improved educational resources and family support groups need to be available;

3. continuous inservice education for the nursing staff be provided to ensure that patients receive current and correct information;

\section{REFERENCES}

BECKER M AND MAIMAN L. Strategies for enhancing patient compliance. Journal of Communiry Health 1980; 6, 2: 113-131.

COX CL. An interaction model of client health behaviour : theoretical perception for nursing. Advances in Nursing Science 1982; 41-55.

DUNN S M. Reactions to educational techniques : coping strategies for diabetes and learning. Diaberic Medicine 1986; 3: 419-429.

FINNERTY F A. The problem of non-compliance. Medical Times 1978; 106, 5: $71-75$.

GLASGOW R E AND MOCAUL D. Barriers to regimen adherence among persons with insulin-dependent diabetes. Journal of Behavioural Medicine 1986; 9, 1: 65-77.

MCCULLOCK D K, MITCHELL RD AND AMBLER J. Influence of imaginative teaching on diet on compliance and metabolic control on insulin-dependent diabetes. British Medical Journal 1983; 287, 1858-1861.

RUZICK D. Relationship of participation preference and health locus of control in diabetes education. Diabetes Care 1984; 7 , 4: 372-376

SEEDAT $Y R$. Diabetes mellitus and the kidney. Modern Medicine of South Africa, 1985; 49-55. 